ISSN $0258-7122$

Bangladesh J. Agril. Res. 32(3) : 375-385, September 2007

\title{
AN ECONOMIC STUDY OF PLANT NURSERY BUSINESS IN GAZIPUR AND JESSORE DISTRICTS OF BANGLADESH
}

\author{
M. A. Haque ${ }^{1}$, M. A. Monayem Miah ${ }^{2}$ and M. A. Rashid ${ }^{3}$
}

\begin{abstract}
The present study was conducted in Jessore and Gazipur districts during 20022003 to assess the socio-economic status of plant nursery business in Bangladesh. A total of 40 private plant nurseries, four government nurseries (BADC) and six NGO nurseries (BRAC) were selected for the study. The study revealed that $60 \%$ of the private nursery owners had secondary level of education and 50\% owners performed their business on leased land. More than $55 \%$ owners had 6-10 years of experience in nursery business. This business has vast potentials of generating employment and income of the owners. The yearly net returns per ha for private, government, and NGO nursery were Tk. 215766, Tk. 120149, and Tk. 535961, respectively. The rates of returns over full-cost were found to be 1.43 for private, 1.37 for government, and 1.50 for NGO nurseries. Non-availability of improved seeds/seedlings was the main constraint for private and NGO nurseries, whereas lack of adequate fund was the crucial problem for government nurseries.
\end{abstract}

\section{Introduction}

Bangladesh is an agro-based country where 85 percent people live in rural areas. They have mostly nutritional deficiency. In order to meet the nutritional demand of increasing population of the country, huge amount of fruits and vegetables need to be produced. The government of Bangladesh has, therefore, given special emphasis for planting different fruit trees and medicinal plants over the country. In this situation, improved variety of fruit and medicinal saplings/seedlings are very essential for distribution among the farmers and other enthusiastic people. A huge number of private, NGOs, and government plant nurseries have been established in different parts of the country and are playing an important role for successful implementation of tree plantation as well as forestation programme in the country. Unfortunately, except some economic studies (Islam et al., 1998), no study has been conducted for this plant nursery management or nursery business. Therefore, detail information about the plant nursery business would help the researchers as well as policy makers for the improvement of the business.

\footnotetext{
${ }^{1}$ Senior Scientific Officer, RARS, BARI, Jessore, ${ }^{2}$ Senior Scientific Officer, Agricultural Economics Division, BARI, Joydebpur, Gazipur, Email: monayem@yahoo.co.in ${ }^{3}$ Senior Scientific Officer, Oilseed Research Centre, BARI, Joydebpur, Gazipur, Bangladesh.
} 
Nevertheless, the findings of the study will encourage more entrepreneurs to invest in setting plant nursery which will contribute a lot to the national forestation programme in Bangladesh. Therefore, the present study has been undertaken in order to: (i) know the socio-economic conditions of private plant nursery owners; (ii) find out the income and employment potentials of plant nursery business; and (iii) identify the socio-economic constraints to plant nursery business.

\section{Materials and Method}

The study was conducted in two Sadar upazilas of Jessore and Gazipur districts where the plant nurseries of private, NGO, and government have been established. The sample plant nurseries were selected with consultation of the concerned personnel of the nursery. A total of 40 private plant nursery owners, taking 20 owners from each area were purposively selected for the study. Besides, two government nurseries (BADC) and three NGO nurseries (BRAC) were also selected from each area for interview. Both horticulture and forest nurseries are operated by private entrepreneurs and NGOs, while only forest nurseries are operated by BADC. The data were collected through survey method by pre-tested interview schedules during December-February 2002-2003.

The collected data were edited, summarized, tabulated, and analyzed to fulfill the objectives of the study. Tabular method was used in analyzing the collected data for the study. Land use cost was calculated on the basis of per year rental value of land. Relative profitability of plant nursery business was examined on the basis of gross margin and net return analysis. Gross return was calculated by multiplying number of seedlings with market price of the seedling. Total variable cost refers to all variable costs including the imputed value of family supplied inputs. Gross margins were calculated by deducting the total variable cost from the gross return. Net return was calculated by deducting total cost from the return.

Weighted scores were calculated against each individual problem faced by the respondents using the following formula for ranking the severity of the nursery business problems.

$$
\text { Weighted Score }=\sum \mathrm{Si}
$$

Where, $S i$ indicates the score given by the respondent for the $\mathrm{i}^{\text {th }}$ problem, and $i=$ $1,2,3 \ldots . . n$ 


\section{Results and Discussion}

\subsection{Socio-economic profile of private nursery owners}

The socio-economic characteristics of the nursery owners revealed that the average family size was 6 which was more or less similar to the national average of 5.6 persons per family (BBS, 1996).

The adult male, female, and children constituted 39\%, 31\%, and 30\% of total family members, respectively. On the average, $35 \%$ of the plant nursery owners had primary level of education, $60 \%$ secondary, and the rest owners had above secondary level of education. About $45 \%$ of the respondents mentioned that their

Table 1. Socio-economic profiles of the private plant nursery owners

\begin{tabular}{l|l|l|l}
\hline Characteristics & Jessore Sadar & Gazipur Sadar & All areas \\
\hline Family size (no./farm) & $6.5(100)$ & $5.7(100)$ & $6.1(100)$ \\
Adult male & $2.4(37)$ & $2.4(42)$ & $2.4(39)$ \\
Adult-female & $1.9(29)$ & $1.9(33)$ & $1.9(31)$ \\
Children (below 13 years) & $2.2(3.4)$ & $1.4(25)$ & $1.8(30)$ \\
Education level (\%) & & & \\
Primary & 30 & 40 & 35 \\
Secondary & 60 & 60 & 60 \\
Above secondary & 10 & - & 5 \\
Occupation (\%) & & & \\
Nursery (sole) & 40 & 50 & 45 \\
Nursery + other agricultural activity & 50 & 50 & 50 \\
Nursery + service & 10 & - & 5 \\
Source of income (\%) & & & 73 \\
Nursery & 74 & 73 & 20 \\
Other agriculture activities & 16 & 23 & 5 \\
Service & 10 & - & 2 \\
$\begin{array}{l}\text { Other } \\
\text { Length of nursery business (\%) }\end{array}$ & - & 4 & 40 \\
Up to 5 years & 60 & 20 & 55 \\
6 to 10 years & 30 & 80 & 5 \\
Above 10 years & 10 & - & 35 \\
Ownership of nursery land (\%) & & & 50 \\
Own & 40 & 30 & 15 \\
Lease & 30 & 70 & \\
Own plus lease & 30 & - & \\
\hline
\end{tabular}

Figures in parenthesis indicated the percentages of total family member.

principal and sole occupation was nursery business and 50\% respondents depended on nursery business along with other agricultural activities (Table 1) Forty-percent of the nursery owners reported that their experience on nursery business was five years, while 55\% reported 6-10 years. Only $5 \%$ of the respondents were experienced by more than 10 
years. In the case of ownership pattern of nursery land, 35\% nursery owners started business on their own lands, 50\% on leased land and only $15 \%$ nursery owners mentioned both own plus leased land. The incomes of the nursery owners come from various sources. It was found that the main sources of income of the $73 \%, 20 \%$, and $7 \%$ of the respondents were plant nursery, agricultural activities, and poultry business, respectively.

\subsection{Land distribution pattern of sample plant nurseries}

The average area per plant nursery was found to be 0.186 ha, which covered $25 \%$ of the total cultivated land. The area of government plant nursery and NGO plant nursery was 3.753 and 0.425 ha, respectively (Table 2).

The private and NGO nurseries in the study areas produce different types of saplings/seedlings and cutting of fruits, forest trees, and flowers. Government nurseries produce different types of saplings/seedlings of fruit, flower, and ornamentals. They do not produce forest trees as it is assigned to the Department of Forest. The names of the fruits, flowers, ornamentals, and forest plants produced in different sample nurseries are given in Appendix 1 and the prices of saplings are given in Appendix 2.

Table 2. Land distribution pattern of private plant nursery owners.

\begin{tabular}{l|c|c|c}
\hline \multirow{1}{*}{ Types of land } & \multicolumn{3}{c}{ Area (ha/farm) } \\
\cline { 2 - 4 } & Jessore Sadar & Gazipur Sadar & All area \\
\hline Owned cultivated land & 0.696 & 0.551 & 0.623 \\
Homestead land & 0.073 & 0.061 & 0.069 \\
Fallow & & 0.028 & 0.012 \\
Rented in & 0.150 & 0.073 & 0.113 \\
Total cultivated land & 0.846 & 0.623 & 0.737 \\
Land under private plant nursery & $0.215(25)$ & $0.158(25)$ & $0.186(25)$ \\
Land under government plant nursery & 1.215 & 6.291 & 3.753 \\
Land under NGO plant nursery & & 0.850 & 0.425 \\
\hline
\end{tabular}

Figures within parentheses indicate the percentage of total cultivated lands

\subsection{Input use pattern of different plant nurseries}

The number of labourers required for private nursery management was estimated to be 2566 man-days/ha/year. The shares of family and hired labour were $52 \%$ and $48 \%$, respectively. The private nursery owners used $21650 \mathrm{~kg}$ cowdung and $610 \mathrm{~kg}$ oilcake as manure, and $615 \mathrm{~kg}$ urea, $1203 \mathrm{~kg}$ TSP, and $531 \mathrm{~kg}$ MP as fertilizers per ha nursery (Table 3). In the case of government nursery, 1771 mandays of human labour were required per year. The government authority used $5676 \mathrm{~kg}$ cowdung and $54 \mathrm{~kg}$ oilcake as manures, and $183 \mathrm{~kg}$ urea, $326 \mathrm{~kg}$ TSP, 
and $198 \mathrm{~kg}$ MP as chemical fertilizer per ha of nursery. NGO nursery used 1719 man-days of human labour per year for their one ha of nursery management. They also used $32900 \mathrm{~kg}$ cowdung and $1976 \mathrm{~kg}$ oilcake, $823 \mathrm{~kg}$ urea, $618 \mathrm{~kg}$ TSP and $605 \mathrm{~kg}$ MP for producing sapling/seedling and cutting of different fruits, ornamentals, flowers, and forest trees per ha nursery, respectively. NGO nursery used higher amounts of inputs like seedling, manure, soil, polythene, and insecticides compared to private and government nurseries (Table 3).

\subsection{Cost of plant nursery business}

The variable cost of plant nursery included the cost of human labour, seeds/seedlings, organic manures, chemical fertilizers, soil, earthen tob, polythene, irrigation, insecticides, and interest on operating capital. On the other hand, the fixed cost included cost of family labour, cost of land use, and depreciation of tools \& equipment. The total cost of plant nursery business under private management was Tk. 496501 per ha on full-cost and Tk. 3,24,952 on cash-cost basis. The cost of human labour was the highest cost item accounting for $35 \%$ of the total cost followed by the cost of seeds/seedlings (Table 3).

In government nurseries, the average per ha cost was estimated at Tk. $3,21,897$ on full-cost basis and Tk. 1,62,436 on cash-cost basis. The cost of human labour and seeds/seedlings were the highest cost items constituting 39\% of total cost of nursery (Table 3)

The average cost of NGO nursery on full-cost and cash-cost basis was Tk. 10,72,713 and Tk. 7,53,975, respectively. Seeds/seedlings was the highest cost item that shared $64 \%$ of total cost of production. The second highest cost item (10\%) was the human labour. The cost of NGO nursery was found much higher than that of private and government nursery due to use of higher amounts of inputs (Table 3). 
Table 3. Input use pattern and cost of different categories of plant nursery.

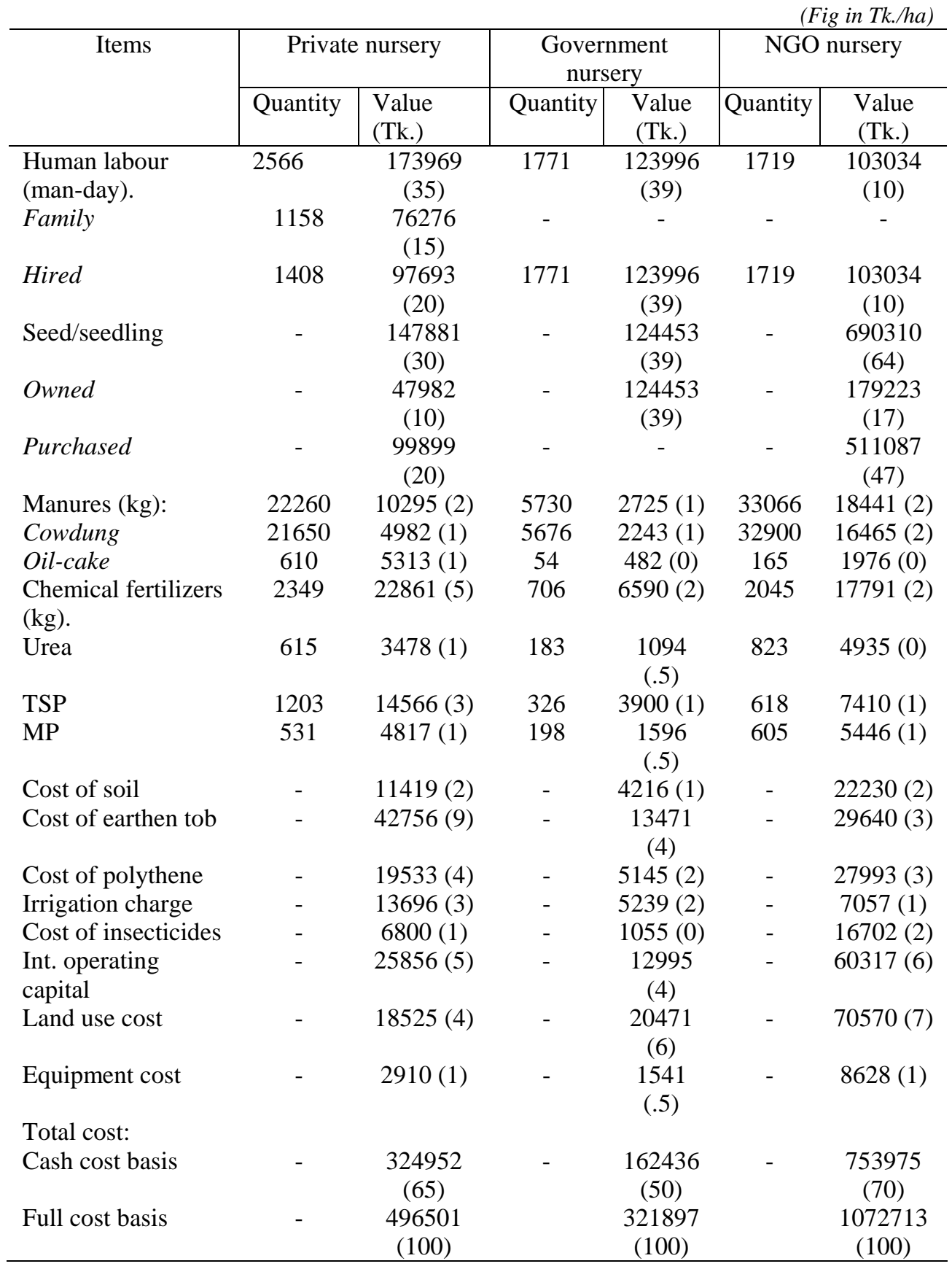

Figures within parentheses indicate percentages of total casts. 


\subsection{Profitability of plant nursery business}

The income of plant nursery owners came from selling of saplings/seedlings of fruits, flowers/ornamentals and wood/forest plants. The private nursery owners in the study areas received Tk. 2,15,766 and Tk. 38,7,315 per ha as net return on full-cost and cash-cost basis, respectively. The highest return was received from the sale of sapling of wood/forest plants followed by fruits and flowers/ornamentals (Table 4). The rate of return (BCR) on full-cost and cashcost basis was 1.43 and 2.19, respectively, indicating that the private plant nursery business was a profitable venture.

The highest source of income of government plant nursery was the sale of fruit sapling (94\%) followed by flowers/ornamental plants. On average, government plant nursery earned Tk. 1,20,149 on full-cost basis and Tk. 2,79,610 on cash-cost basis per ha as net return. The BCR on both full-cost and cash-cost basis were 1.37 and 2.72, respectively.

A sample plant nursery under NGO management generated Tk. 5,35,961 and Tk. 8,54,699 per ha as net return on full-cost and cash-cost basis, respectively. The major income of NGO nursery came from fruit's sapling followed by wood/forest plants. The rates of returns (BCR) on both full-cost and cash-cost basis were estimated at 1.50 and 2.13, respectively (Table 4).

Table 4. Costs and returns of different categories of plant nursery.

\begin{tabular}{l|lll}
\hline \multirow{1}{*}{ Items } & \multicolumn{3}{c}{ Categories of plant nursery } \\
\cline { 2 - 4 } & Private nursery & $\begin{array}{l}\text { Government } \\
\text { nursery }\end{array}$ & NGO nursery \\
\hline Total cost (Tk/ha): & 496501 & 321897 & 1072713 \\
Full-cost basis & 324952 & 162436 & 753975 \\
Cash-cost basis & 712267 & 442046 & 1608674 \\
Total return (Tk./ha): & $201834(28)$ & $414147(94)$ & $769743(48)$ \\
Fruit's sapling & $195819(27)$ & $27899(06)$ & $335219(21)$ \\
Flowers/ornamentals & $314614(45)$ & - & $503712(31)$ \\
Wood/forest plants & & & 535961 \\
Net return (Tk/ha): & 215766 & 120149 & 854699 \\
Full cost basis & 387315 & 279610 & 1.50 \\
Cash cost basis & & & \\
Rate of return (BCR): & 1.43 & 1.37 & \\
Full cost basis & 2.19 & 2.72 & \\
Cash cost basis & & \multicolumn{3}{l}{} \\
\hline
\end{tabular}

Figures within parentheses are the percentages of total returns.

Returns to investment of various production inputs in nursery business are shown in Table 5. All the inputs produced more than one taka by investing one taka in nursery business. The highest return was produced by applying insecticides and 
manure. Fertilization and irrigating the crop also gave higher returns to investment.

Table 5. Returns to different inputs used in different categories of plant nursery.

(per taka invested)

\begin{tabular}{l|l|l|l}
\hline \multirow{2}{*}{ Items } & \multicolumn{3}{|c}{ Category of plant nursery } \\
\cline { 2 - 4 } & Private nursery & $\begin{array}{l}\text { Government } \\
\text { nursery }\end{array}$ & NGO nursery \\
\hline Returns to human & 2 & 2 & 7 \\
labour & & 2 & 2 \\
Returns to seed/seedling & 3 & 53 & 34 \\
Returns to manure & 24 & 23 & 36 \\
Returns to fertilizer & 11 & 28 & 32 \\
Returns to irrigation & 18 & 43 & 37 \\
Returns to insecticides & 36 & & \\
\hline
\end{tabular}

\subsection{Problems faced by plant nursery owners}

The respondents were asked to give their opinion regarding the problems of plant nursery business. In this respect, respondents expressed more than one opinion which was ranked according to the importance of problems.

The study revealed that non-availability of improved seed/seedling in the study areas was the crucial problem for private and NGO plant nurseries. On the other hand, the lack of adequate fund was the first ranked problem for government nursery. The second most important problem faced by all nursery owners was low price of sapling and seedling. The other socio-economic problems of nursery business were damage of seedling, lack of efficient labour, attack of insect and diseases, lack of technical know-how, inadequate irrigation and credit facilities (Table 6).

Table 6. Constraints of different categories of plant nursery.

\begin{tabular}{|c|c|c|c|}
\hline \multirow[t]{2}{*}{ Constraints } & \multicolumn{3}{|c|}{ Rank value } \\
\hline & $\begin{array}{l}\text { Private } \\
\text { nursery }\end{array}$ & $\begin{array}{l}\text { Government } \\
\text { nursery }\end{array}$ & $\begin{array}{l}\text { NGO } \\
\text { nursery }\end{array}$ \\
\hline Lack of adequate fund & 5 & 1 & - \\
\hline $\begin{array}{l}\text { Inadequate supply of improved } \\
\text { seed/seedling }\end{array}$ & 1 & 3 & 1 \\
\hline Lack of technical know-how & 6 & - & - \\
\hline Low price of sapling/seedling & 2 & 2 & 2 \\
\hline Lack of efficient labour & 4 & - & 3 \\
\hline Damage of sapling/seedling & 3 & 4 & 4 \\
\hline Infestation of insects and diseases & 5 & 5 & 5 \\
\hline Lack of irrigation facilities & 7 & - & 6 \\
\hline Lack of credit facilities & 8 & - & - \\
\hline
\end{tabular}




\section{Conclusions}

The findings of the study reveal that the level of education and experience regarding nursery business are quite satisfactory. Besides, the nursery business is found to be a profitable business in the study areas. All the nurseries under different managements generate a substantial number of employment and income for the owners. The cost of production, gross margin, and net return are much higher for NGO plant nursery as compared to private and government plant nursery. Returns to investment in the use of fertilizer and irrigation are found to be higher for NGO plant nursery, whereas returns to manure and insecticide are higher for government plant nursery. The findings of the study also reveal that various socio-economic problems, to some extent, hamper the nursery business in the study areas.

General people are highly benefiting by getting sapling of fruit trees from different plant nurseries and are contributing, to some extent, to the ecological balance of the country by planting of these saplings. Therefore, government should release adequate fund for the plant nursery so that private nursery owners as well as NGOs can also receive improved saplings of different trees from government nurseries. Besides, government should provide training to the private nursery owners and NGO personnel on improved nursery management techniques.

\section{References}

BBS. 1996. Bangladesh Bureau of Statistics. Statistical Yearbook of Bangladesh. Ministry of Planning, Government of Bangladesh.

Islam, S.S., M.G. Kibria; and M.H. Chowdhury. 1998. Financial analysis of agroforestry trial at Ichamati, Chittagong. Bangladesh Journal of Forest Science 27(2): 76-81. 


\section{Appendix-1}

Name of fruit, flower and ornamental plants

\begin{tabular}{|c|c|c|}
\hline Local Name & English Name & Scientific Name \\
\hline \multicolumn{3}{|l|}{ A. Fruit trees } \\
\hline 1. Aam & Mango & Mangifera indica \\
\hline 2. Peyara & Guava & Psidium guajava \\
\hline 3. Lichu & Litchi & Litchi chinensis \\
\hline 4. Kagozilebu & Lime & Citrus aurantifolia \\
\hline 5. Katal & Jackfruit & Artocarpus heterophyllus \\
\hline 6. Jolpai & Olive & Olea europaea \\
\hline 7. Kamranga & Carambola & Averrhoo carambola \\
\hline 8. Jaam & Jamun & Syzygium cumini \\
\hline 9. Jumrul & Wax Jambu & Syzygium samarangense \\
\hline 10. Sopheda & Sapota & Manilkara achras \\
\hline 11. Dalim & Pomegranate & Punica granatum \\
\hline 12. Angur & Grape & Vitis vinifera \\
\hline 13. Рара & Papaya & Carica papaya \\
\hline 14. Amra & Golden apple & Spondias cythera \\
\hline 15. Narical & Coconut & Cocos nucifera \\
\hline 16. Supari & Nut & - \\
\hline \multicolumn{3}{|l|}{ B. Flowers } \\
\hline 1. Golap & Rose & Rose sp. \\
\hline 2. Hasnahena & Cestrum & Cestrum aurantiacum \\
\hline 3. Gondharaj & Gardenia & Gardenia fasminoides \\
\hline 4. Gada & African marigold & Tageles erecia \\
\hline 5. Bely & Arabian Jasmine & jasminum sambac \\
\hline 6. Zaba & China rose & Hisbiscus rosasinenris \\
\hline 7. Baganbilash & Bougainvillea & Bougainvillea sp. \\
\hline 8. Kamini & China box & Murraya exotica \\
\hline 9. Dalia & Dahlia & Dahlia sp. \\
\hline 10. Mouchandra & Mussaenda & Mussaenda ergthrophylla \\
\hline 11. Chandramollika & Chrysanthemum & Chrysanthemum segetum \\
\hline 12. Jhau & Australian oak & Casurina equisatifolia \\
\hline 13. Patabahar & Croton & Codiaeum variegatum \\
\hline 14. Togor & Cape jasmine & Tabernaemontana cronaria \\
\hline 15. Rangon & Lxora & Lxora sp. \\
\hline 16. Salvia & Salvia & Salvia splendens \\
\hline 17. Star & Newyork aster & Asternovi belgu \\
\hline \multicolumn{3}{|l|}{ C. Wood tree } \\
\hline 1. Segun & Sagun & Tectona grandis \\
\hline 2. Mehoguni & Mehoguni & Swietenia macrophylla \\
\hline 3. Shisu & Sissoo & Dalbergia sissoo \\
\hline 4. Shilkoroi & Shilkorio & Mimosoideae \\
\hline 5. Raintree & Raintry & Samanea saman \\
\hline 6. Nim & $\mathrm{Nim}$ & Azadirachta indica \\
\hline 7. Arjun & Arjun & Terminalia arjuna \\
\hline
\end{tabular}




\section{Appendix-2}

Prices of saplings/seedlings for different nurseries

\begin{tabular}{l|c|c|c}
\hline Sapling/seedling & Private nursery & $\begin{array}{c}\text { Government } \\
\text { nursery }\end{array}$ & NGO nursery \\
\hline 1. Fruit trees & $03-50$ & $05-20$ & $10-100$ \\
2. Wood trees & $02-15$ & $05-10$ & $10-20$ \\
3. Flowers/ornamentals & $0.50-15$ & - & $10-70$ \\
\hline
\end{tabular}

